\title{
Agronomic performance and pod shattering resistance of soybean genotypes with various pod and seed colors
}

\author{
AYDA KRISNAWATI", M. MUCHLISH ADIE \\ Indonesian Legume and Tuber Crops Research Institute. Jl. Raya Kendalpayak Km 8, Malang 65162, East Java, Indonesia \\ Tel.: +62-341-801468, 801075, Fax.: +62-341-801496, ^email: aydakrisnawati@ pertanian.go.id \\ Manuscript received: 4 December 2020. Revision accepted: 29 December 2020.
}

\begin{abstract}
Krisnawati A, Adie MM. 2021. Agronomic performance and pod shattering resistance of soybean genotypes with various pod and seed colors. Biodiversitas 22: 472-479. Climate change impacts agricultural production, including the increase of the yield loss in soybean due to pod shattering. This research aimed to identify the pod shattering resistance and agronomic performance of several soybean genotypes with various pod and seed colors. A total of 100 soybean genotypes were planted in Malang (East Java, Indonesia) during the dry season 2019. The field experiment was laid out in a randomized block design with three replications. The pod shattering resistance was assessed using the oven-dry method. The pod shattering resistance of 97 genotypes were classified into 20 very resistant genotypes, 17 resistant genotypes, 15 moderate genotypes, nine susceptible, and 36 very susceptible genotypes. The pod colors did not affect the pod shattering resistance in soybean. The new findings from this study, i.e., two very resistant genotypes (G42 and G15) which produce high yield and have medium maturity, were suggested to be developed as new cultivars, meanwhile, the other very resistant genotypes can be used in the soybean breeding program to develop shattering resistant cultivar with desirable traits.
\end{abstract}

Keywords: High yield, genetic background, oven-dry method, selection, yield loss

\section{INTRODUCTION}

Soybean is periodically planted in Indonesia during the second dry season (June/July until September/October). Therefore, the generative stage of soybean from the seed filling period to the pod maturation may occur in hot weather conditions which trigger a higher incidence of pod shattering. The negative impact of pod shattering is the release of seeds from the pod and drops to the ground, hence it reduces the harvestable yield and leading to significant yield losses. The yield loss in soybean due to pod shattering may range from $34 \%$ to $100 \%$ (Tiwari and Bhatnagar 1991; Tefera et al. 2009) depending on the genetic constitution of the variety and environmental factors (Tukamuhabwa et al. 2002; Ogutcen et al. 2018; Nevhudzholi et al. 2020). Bara et al. (2013) reported that high temperatures during the time of maturity caused severe pod-shattering incidence. Meanwhile, Zhang and Boahen (2010) found that irrigated and non-irrigated conditions caused a difference in the pod shattering resistance among soybean varieties.

Identification of the soybean resistance for pod shattering in several genotypes has been conducted in numerous studies. In Indonesia, a selection of 591 of fifth set offspring (F5) soybean population derived from six pedigree has obtained 104 resistant lines to pod shattering (Krisnawati et al. 2019a). A similar study was conducted on the ten soybean promising lines and it obtained a resistant genotype to shattering (Krisnawati et al. 2019b). In other countries, such as Ghana, the screening for shattering resistance on soybean has successfully obtained six genotypes (SIT-M TGx1904-6F, SIT-E TGx1835-10E,
SIT-M TGx1987-40F, TGx1903-7F, SIT-E TGx1448-2E, and Anidaso) with moderate resistance to pod shattering (Antwi-Boasiako 2017). In India, soybean genotype NRC 7 was found to be resistant to pod shattering, meanwhile, EC 241780 and Kalitur were susceptible (Bhor et al. 2014).

The studies to investigate the agronomic characteristics related to pod shattering resistance have been carried out. The pod characters were reported to be involved in the shattering of soybean (Bara et al. 2013). Adeyeye et al. (2014) found a significant negative correlation between pod-shattering with pod diameter while plant height had a negative but not significant effect on the number of shattered pods per plant. A newer study found that pod shattering resistance was negatively correlated with the number of seeds per pod, which means that plants with few seeds per pod tended to have high resistance to pod shattering (Kataliko et al. 2019). These facts show that pod characters could play an important role in the shattering incidence.

The soybean pod is an important component of the plant, where the seed would be placed and become the occurrence of shattering. There is a large variation in the pod wall and seed color of soybean (De Chavez et al. 2016). Several studies have documented that the pod and seed color have multifaceted effects on the agronomic characteristics of the soybean and stress resistance (He et al. 2015; Liu et al. 2017). Zhao et al. (2008) reported that soybeans with the light color of the pod coat tend to have greater resistance to pod borer than soybeans with darkcolored pods. Another study found a difference in the shattering resistance among seed colors in Brassica species (Wang et al. 2007). However, the identification of the 
effect of pod and seed colors in the pod shattering resistance of soybean has not been reported yet. Furthermore, the combination of high pod shattering resistance and good agronomic characters as well as high productivity in the newly developed genotypes could benefit soybean growers.

Thus, this research aimed to identify the pod shattering resistance and agronomic performance of several soybean genotypes with various pod and seed colors.

\section{MATERIALS AND METHODS}

\section{Study area}

The field experiment was conducted during the first dry season (March to June 2019) in Kepanjen (Malang, East Java, Indonesia), which located at $8^{\circ} 10^{\prime} 30^{\prime \prime S}$, $112^{\circ} 33^{\prime} 32.4^{\prime \prime E}$. The elevation was $335 \mathrm{~m}$ asl., with E3 Oldeman climate type, rainfall of $2200 \mathrm{~mm} /$ year, and the soil type of alfisol. The minimum and maximum temperatures were $23.5^{\circ} \mathrm{C}$ and $32^{\circ} \mathrm{C}$, respectively, and the relative humidity was $79 \%$.

\section{Plant materials and field study}

The research materials were 100 soybean genotypes consisting of 97 genotypes derived from 14 pedigree, and three check cultivars (Dega 1, Derap 1, and Detap 1) (Table 1 ). The field experiment was conducted in the wetland with the soil tillage and laid out in a randomized block design with three replications. Each genotype was planted in a plot size of $0.8 \mathrm{~m} \times 4.5 \mathrm{~m}$ with the plant spacing of $40 \mathrm{~cm} \times 15$ $\mathrm{cm}$, two plants per hill. Plants were fertilized by $50 \mathrm{~kg} / \mathrm{ha}$ urea, $100 \mathrm{~kg} / \mathrm{ha} \mathrm{SP} 36$, and $75 \mathrm{~kg} / \mathrm{ha} \mathrm{KCl}$ which applied entirely at the sowing time. The pests, diseases, and weeds were optimally managed. Plants were harvested at full maturity $\left(\mathrm{R}_{8}\right.$ stage). The $\mathrm{R}_{8}$ stage is determined when $95 \%$ of the pods have reached their mature brown color.

\section{Pod shattering evaluation}

The screening for pod shattering resistance was conducted in the laboratory. When plants at the $\mathrm{R}_{8}$ stage, three sample plants were randomly taken from each plot (or combination of the genotype and replication). Plants were then dried at room temperature for three days. Thirty pods were randomly detached from those three sample plants and then placed in a petridish $(\varnothing=15 \mathrm{~cm})$ for shattering evaluation based on the oven-dry method (Krisnawati et al. 2019a), i.e., the pods were dried at $30^{\circ} \mathrm{C}$ for three days, and then elevated to $40^{\circ} \mathrm{C}$ (one day), $50^{\circ} \mathrm{C}$ (one day), and $60^{\circ} \mathrm{C}$ (one day). The experiment was arranged in a complete randomized design with three replications according to the field experimental design.

\section{Data collection}

Agronomic data from the field experiment were collected on the days to maturity, days to flowering, and seed yield. The seed yield was observed based on the population of plants per plot, and converted to t/ha. The observation was also made on the pod wall color and seed coat color for each genotype. The data from the laboratory experiment consist of pod shattering percentage of each genotype. The pod-shattering percentage was observed after being subjected to $60^{\circ} \mathrm{C}$. The shattering percentage was the number of the shattered pods divided by the number of sample pods (thirty pods), in percentage.

\section{Data analysis}

The agronomic and pod shattering resistance data were expressed as descriptive statistics (minimum and maximum value, standard deviation, and mean). The variability of the pod as seed colors was visualized in pie charts. The agronomic data were also visualized in scatter diagrams. The seed yield of selected genotypes was visualized in a column chart. The grouping of pod shattering resistance based on the shattering percentage was following the AVRDC (1979): very resistant (0\%), resistant (1-10\%), moderate (11-25\%), susceptible (26-50\%), and very susceptible $(>50 \%)$. The difference in the pod shattering among various seed and pod colors was investigated by Welch's t-test using Minitab ver. 17.1.0 (Minitab 2013).

\section{RESULTS AND DISCUSSION}

\section{Characteristics of agronomic traits}

The agronomic characteristics of 100 soybean genotypes consisted of days to flowering, days to maturity, and seed yield. Descriptive statistics of these characters are detailed in Table 2. The days to flowering ranged from 3341 days with an average of 35 days, meanwhile, the range of days to maturity was from 77-81 days with an average of 80 days. The soybean classification for days to maturity in Indonesia was grouped into late maturity (> 90 days), medium maturity (80-90 days), and early maturity ( $<80$ days). Then, the days to maturity of 100 genotypes ranged from early to medium maturity. The seed yield of all genotypes ranged from $0.52-3.30$ t/ha with an average of $1.86 \mathrm{t} / \mathrm{ha}$. The graphical data of the days to flowering and days to maturity of 100 soybean genotypes were presented in Figure 1, meanwhile, the seed yield data were shown in Figure 2.

\section{Characteristics of pod and seed}

The genotypes used in this study were derived from the selection of crossing of diverse parental, hence the pod and seed color showed a large variation, include the check cultivars (Figure 3 ). The pod color was dominated by the dark brown color (47 genotypes), followed by yellow color (39 genotypes), light brown (ten genotypes), and brown pod color (four genotypes). The seed color varies from yellow to black. A total of 69 genotypes have yellow seed coat, 19 genotypes with black seed coat, and twelve genotypes have green seed coat. The pod and seed color are frequently used in variety description and identification due to their distinguishable classes of pod color (Ramteke and Murlidharan 2012) and as markers to assess hybridity in breeding programs (Yang et al. 2010; Shingare et al. 2020). The variation in the pod and seed colors was presented in Figure 4. 


\section{The classification for pod shattering resistance}

The shattering resistance inherited from the diverse parental of 97 genotypes showed a large variation of resistance (Table 3, Figure 5). Genotypes with genetic background from the parental of Anjasmoro variety tend to show resistance to pod shattering. Similarly, Krisnawati et al. (2020), using Anjasmoro variety for genetic improvement through hybridization resulted in five F8 resistant lines that have comparable resistance with the check cultivar (Detap 1). The previous selection study also reported the effectiveness of Anjasmoro variety as a parental line to produce shatter-resistant genotypes (Krisnawati et al. 2019a).

Table 1. List of pedigree, generation, and parental genotypes used in this study

\begin{tabular}{|c|c|c|c|c|}
\hline \multirow{2}{*}{ Code } & \multirow{2}{*}{ Pedigree } & \multirow{2}{*}{ Gen. } & \multicolumn{2}{|c|}{ Parental } \\
\hline & & & Female & Male \\
\hline G1 & Grobogan/Dg-210 & $\mathrm{F}_{6}$ & Grobogan & Degra \\
\hline $\mathrm{G} 2$ & Grobogan/Dg-246 & $\mathrm{F}_{6}$ & Grobogan & Degra \\
\hline G3 & Dg/Grobogan-255 & $\mathrm{F}_{6}$ & Degra & Grobogan \\
\hline G4 & Dg/Grobogan-258 & $\mathrm{F}_{6}$ & Degra & Grobogan \\
\hline G5 & Grobogan/Dg-264 & $\mathrm{F}_{6}$ & Grobogan & Degra \\
\hline G6 & Grobogan/Dg-269 & $\mathrm{F}_{6}$ & Grobogan & Degra \\
\hline G7 & Grobogan/Dg-271 & $\mathrm{F}_{6}$ & Grobogan & Degra \\
\hline G8 & Grobogan/Dg-272 & $\mathrm{F}_{6}$ & Grobogan & Degra \\
\hline G9 & Grobogan/Dg-288 & $\mathrm{F}_{6}$ & Grobogan & Degra \\
\hline G10 & Grobogan/Dg-289 & $\mathrm{F}_{6}$ & Grobogan & Degra \\
\hline G11 & Grobogan/Dg-381 & $\mathrm{F}_{6}$ & Grobogan & Degra \\
\hline G12 & Grobogan/G100H-417 & $\mathrm{F}_{6}$ & Grobogan & $\mathrm{G} 100 \mathrm{H}$ \\
\hline G13 & Mahameru/IAC100-423 & $\mathrm{F}_{6}$ & Mahameru & IAC100 \\
\hline G14 & Dega 1/Dg-493 & $\mathrm{F}_{6}$ & Dega 1 & Degra \\
\hline G15 & Dega 1/Dg-507 & $\mathrm{F}_{6}$ & Dega 1 & Degra \\
\hline G16 & Dega $1 / \mathrm{Dg}-510$ & $\mathrm{~F}_{6}$ & Dega 1 & Degra \\
\hline G17 & Dega 1/Dg-512 & $\mathrm{F}_{6}$ & Dega 1 & Degra \\
\hline G18 & Anjasmoro/Dg-525 & $\mathrm{F}_{6}$ & Anjasmoro & Degra \\
\hline G19 & Anjasmoro/Dg-526 & $\mathrm{F}_{6}$ & Anjasmoro & Degra \\
\hline $\mathrm{G} 20$ & Anjasmoro/Dg-536 & $\mathrm{F}_{6}$ & Anjasmoro & Degra \\
\hline $\mathrm{G} 21$ & Anjasmoro/Dg-536 & $\mathrm{F}_{6}$ & Anjasmoro & Degra \\
\hline $\mathrm{G} 22$ & Dg/Anjasmoro-564 & $\mathrm{F}_{6}$ & Degra & Anjasmoro \\
\hline $\mathrm{G} 23$ & Dg/Anjasmoro-570 & $\mathrm{F}_{6}$ & Degra & Anjasmoro \\
\hline G24 & Dg/Anjasmoro-577 & $\mathrm{F}_{6}$ & Degra & Anjasmoro \\
\hline G25 & Grobogan/G100H-582 & $\mathrm{F}_{6}$ & Grobogan & $\mathrm{G} 100 \mathrm{H}$ \\
\hline G26 & Grobogan/Dg-652 & $\mathrm{F}_{6}$ & Grobogan & Degra \\
\hline G27 & Grobogan/Dg-654 & $\mathrm{F}_{6}$ & Grobogan & Degra \\
\hline G28 & Grobogan/Dg-716 & $\mathrm{F}_{6}$ & Grobogan & Degra \\
\hline G29 & Grobogan/Dg-720 & $\mathrm{F}_{6}$ & Grobogan & Degra \\
\hline G30 & Grobogan/Dg-724 & $\mathrm{F}_{6}$ & Grobogan & Degra \\
\hline G31 & Grobogan/Dg-727 & $\mathrm{F}_{6}$ & Grobogan & Degra \\
\hline G32 & Grobogan/Dg-747 & $\mathrm{F}_{6}$ & Grobogan & Degra \\
\hline G33 & Grobogan/Dg-760 & $\mathrm{F}_{6}$ & Grobogan & Degra \\
\hline G34 & Grobogan/Dg-761 & $\mathrm{F}_{6}$ & Grobogan & Degra \\
\hline G35 & Grobogan/Dg-763 & $\mathrm{F}_{6}$ & Grobogan & Degra \\
\hline G36 & Dg/Mahameru-790 & $\mathrm{F}_{6}$ & Degra & Mahameru \\
\hline G37 & Mahameru/Dg-813 & $\mathrm{F}_{6}$ & Mahameru & Degra \\
\hline G38 & Mahameru/Dg-814 & $\mathrm{F}_{6}$ & Mahameru & Degra \\
\hline G39 & Mahameru/Dg-842 & $\mathrm{F}_{6}$ & Mahameru & Degra \\
\hline G40 & Grobogan/G100H-875 & $\mathrm{F}_{6}$ & Grobogan & $\mathrm{G} 100 \mathrm{H}$ \\
\hline G41 & Grobogan/G100H-877 & $\mathrm{F}_{6}$ & Grobogan & $\mathrm{G} 100 \mathrm{H}$ \\
\hline G42 & Grobogan/G100H-879 & $\mathrm{F}_{6}$ & Grobogan & $\mathrm{G} 100 \mathrm{H}$ \\
\hline G43 & Grobogan/G100H-959 & $\mathrm{F}_{6}$ & Grobogan & $\mathrm{G} 100 \mathrm{H}$ \\
\hline G44 & Anjasmoro/Dg-1015 & $\mathrm{F}_{6}$ & Anjasmoro & Degra \\
\hline G45 & Dg/Anjasmoro-1043 & $\mathrm{F}_{6}$ & Degra & Anjasmoro \\
\hline
\end{tabular}

G46 Dg/IAC100-1117

G47 Grobogan/G100H-1173

G48 G2/PR15

G49 Grobogan/Dg-1079

G50 IAC 100/Anjasmoro-1052

G51 IAC 100/Anjasmoro-1053

G52 IAC 100/Anjasmoro-1054

G53 IAC 100/Anjasmoro-1055

G54 IAC 100/Anjasmoro-1056

G55 IAC 100/Anjasmoro-1057

G56 JP15/Anjasmoro-937

G57 JP15/Anjasmoro-941-1

G58 JP15/Anjasmoro-941-2

G59 JP15/Anjasmoro-941-3

G60 JP15/Anjasmoro-946-4

G61 JP15/Anjasmoro-949-5

G62 JP15/Anjasmoro-972-6

G63 JP15/Anjasmoro-990-7

G64 JP15/Anjasmoro-994-8

G65 JP15/Anjasmoro-997-9

G66 Khl/Anjasmoro-1015-1

G67 Khl/Anjasmoro-1015-2

G68 Khl/Anjasmoro-1022-3

G69 JP15/Anjasmoro-1010-10

G70 JP15/Anjasmoro-1010-11

G71 JP15/Anjasmoro-1010-12

G72 JP15/Anjasmoro-1011-13

G73 JP15/Anjasmoro-1011-14

G74 JP15/Anjasmoro-1012-15

G75 JP15/Anjasmoro-1012-16

G76 JP15/Anjasmoro-1025-17

G77 JP15/Anjasmoro-1025-18

G78 JP15/Anjasmoro-1026-19

G79 JP15/Anjasmoro-948-17

G80 JP15/Anjasmoro-1013-20

G81 JP15/Anjasmoro-1013-21

G82 JP15/Anjasmoro-1013-22

G83 JP15/Anjasmoro-1013-23

G84 JP15/Anjasmoro-1013-24

G85 JP15/Anjasmoro-1016-25

G86 JP15/Anjasmoro-1016-26

G87 JP15/Anjasmoro-1023-27

G88 JP15/Anjasmoro-1023-28

G89 JP15/Anjasmoro-1023-29

G90 JP15/Anjasmoro-1027-30

G91 JP15/Anjasmoro-1027-31

G92 JP15/Anjasmoro-1027-32

G93 JP15/Anjasmoro-1027-33

G94 JP15/Anjasmoro-1028-34

G95 JP15/Anjasmoro-1028-35

G96 JP15/Anjasmoro-1028-36

G97 JP15/Anjasmoro-1028-37

G98 Dega 1

G99 Derap 1

G100 Detap 1

Note: Gen: Generation

$\mathrm{F}_{6} \quad$ Degra IAC100

$\mathrm{F}_{6}$ Grobogan $\mathrm{G} 100 \mathrm{H}$

$\mathrm{F}_{6} \quad \mathrm{G} 2 \quad \mathrm{PR} 15$

$\mathrm{F}_{6}$ Grobogan Degra

F6 IAC100 Anjasmoro

$\mathrm{F}_{6}$ IAC100 Anjasmoro

$\mathrm{F}_{6} \quad$ IAC100 Anjasmoro

$\mathrm{F}_{6} \quad$ IAC100 Anjasmoro

$\mathrm{F}_{6} \quad$ IAC100 Anjasmoro

$\mathrm{F}_{6}$ IAC100 Anjasmoro

$\mathrm{F}_{6} \quad$ JP15 Anjasmoro

$\mathrm{F}_{6}$ JP15 Anjasmoro

$\mathrm{F}_{6} \quad$ JP15 Anjasmoro

$\mathrm{F}_{6} \quad$ JP15 Anjasmoro

$\mathrm{F}_{6}$ JP15 Anjasmoro

$\mathrm{F}_{6} \quad$ JP15 Anjasmoro

$\mathrm{F}_{6}$ JP15 Anjasmoro

$\mathrm{F}_{6} \quad$ JP15 Anjasmoro

$\mathrm{F}_{6} \quad$ JP15 Anjasmoro

$\mathrm{F}_{6} \quad$ JP15 Anjasmoro

$\mathrm{F}_{6} \quad$ Khilau Anjasmoro

$\mathrm{F}_{6} \quad$ Khilau Anjasmoro

F6 Khilau Anjasmoro

$\mathrm{F}_{6}$ JP15 Anjasmoro

$\mathrm{F}_{6} \quad$ JP15 Anjasmoro

$\mathrm{F}_{6} \quad$ JP15 Anjasmoro

$\mathrm{F}_{6}$ JP15 Anjasmoro

$\mathrm{F}_{6}$ JP15 Anjasmoro

F6 JP15 Anjasmoro

$\mathrm{F}_{6} \quad$ JP15 Anjasmoro

$\mathrm{F}_{6} \quad$ JP15 Anjasmoro

$\mathrm{F}_{6} \quad$ JP15 Anjasmoro

$\mathrm{F}_{6}$ JP15 Anjasmoro

$\mathrm{F}_{6}$ JP15 Anjasmoro

$\mathrm{F}_{6}$ JP15 Anjasmoro

$\mathrm{F}_{6} \quad$ JP15 Anjasmoro

$\mathrm{F}_{6} \quad \mathrm{JP15}$ Anjasmoro

$\mathrm{F}_{6} \quad$ JP15 Anjasmoro

$\mathrm{F}_{6} \quad$ JP15 Anjasmoro

$\mathrm{F}_{6}$ JP15 Anjasmoro

$\mathrm{F}_{6}$ JP15 Anjasmoro

$\mathrm{F}_{6} \quad$ JP15 Anjasmoro

$\mathrm{F}_{6} \quad$ JP15 Anjasmoro

$\mathrm{F}_{6} \quad$ JP15 Anjasmoro

F6 JP15 Anjasmoro

$\mathrm{F}_{6} \quad$ JP15 Anjasmoro

$\mathrm{F}_{6}$ JP15 Anjasmoro

$\mathrm{F}_{6} \quad$ JP15 Anjasmoro

$\mathrm{F}_{6} \quad$ JP15 Anjasmoro

$\mathrm{F}_{6} \quad$ JP15 Anjasmoro

$\mathrm{F}_{6} \quad$ JP15 Anjasmoro

$\mathrm{F}_{6} \quad$ JP15 Anjasmoro

Variety Grobogan Malabar

Variety G511H Anjasmoro Variety G511H Anjasmoro

Table 2. Descriptive statistics for the agronomic and pod shattering data of 100 soybean genotypes

\begin{tabular}{lcccc}
\hline \multicolumn{1}{c}{ Character } & Min. & Max. & SD & Mean \\
\hline Days to flowering (days) & 33 & 41 & 1.06 & 35 \\
Days to maturity (days) & 77 & 81 & 1.23 & 80 \\
Seed yield (t/ha) & 0.52 & 3.30 & 0.61 & 1.86 \\
Pod shattering (\%) & 0 & 100 & 40.88 & 40 \\
\hline
\end{tabular}




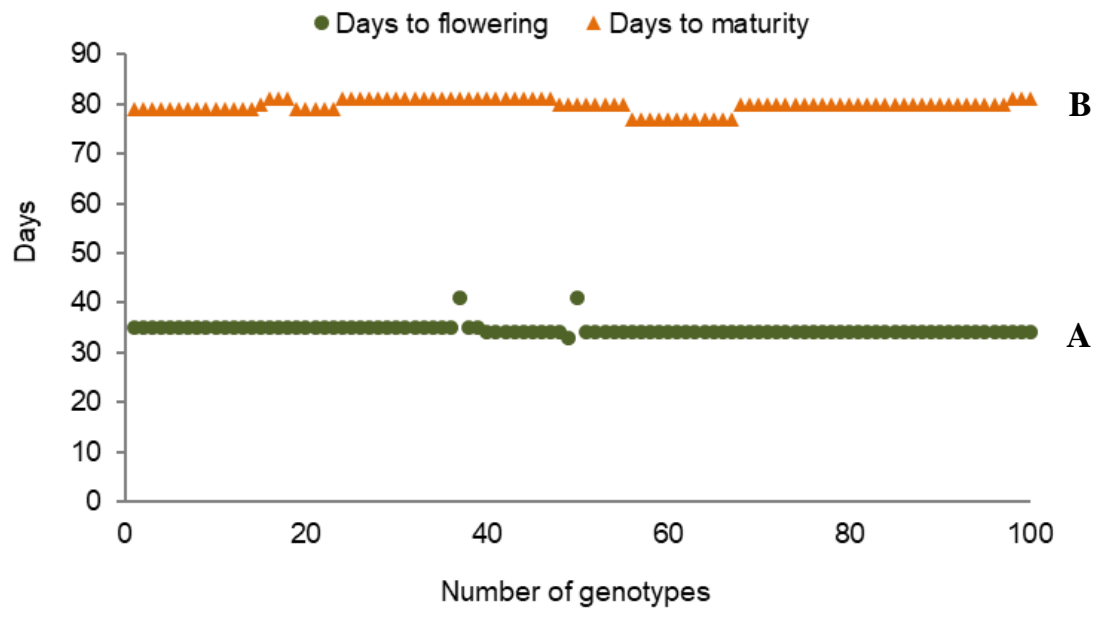

Figure 1. Scatter diagram of the days to flowering (A: green round points) and the days to maturity; B: orange triangle points) of 100 soybean genotypes. The $\mathrm{x}$-axis was the number of genotypes which consist of 100 soybean genotypes. The average of the days to flowering and the days to maturity (y-axis) were 35 days and 80 days, respectively

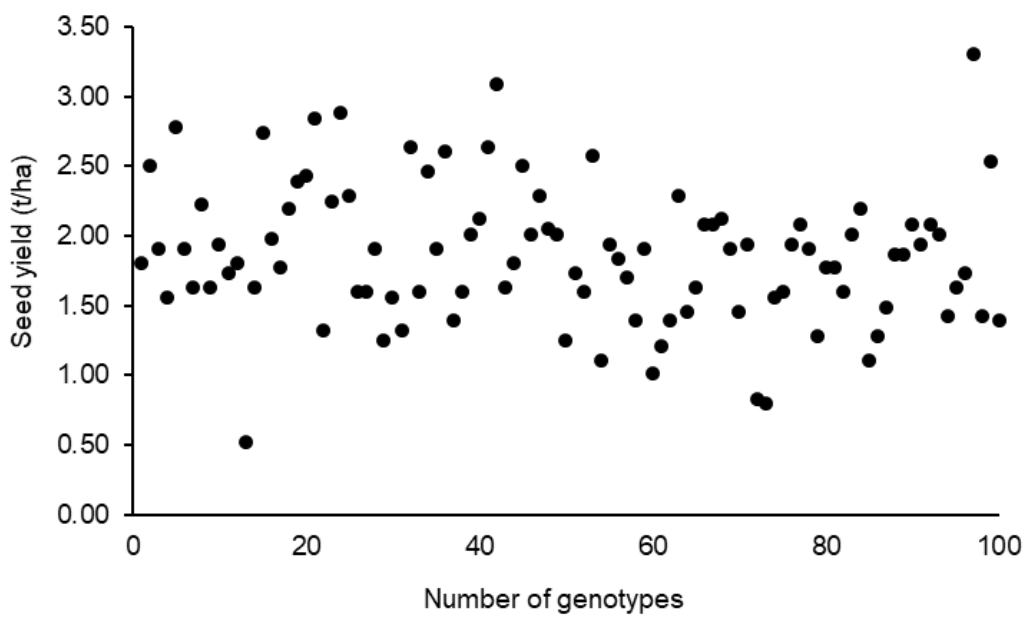

Figure 2. Scatter diagram of seed yield from 100 soybean genotypes planted during the first dry season 2019. The x-axis was number of genotypes which consist of 100 soybean genotypes. The seed yield (y-axis) ranged from $0.52-3.30 \mathrm{t} / \mathrm{ha}$
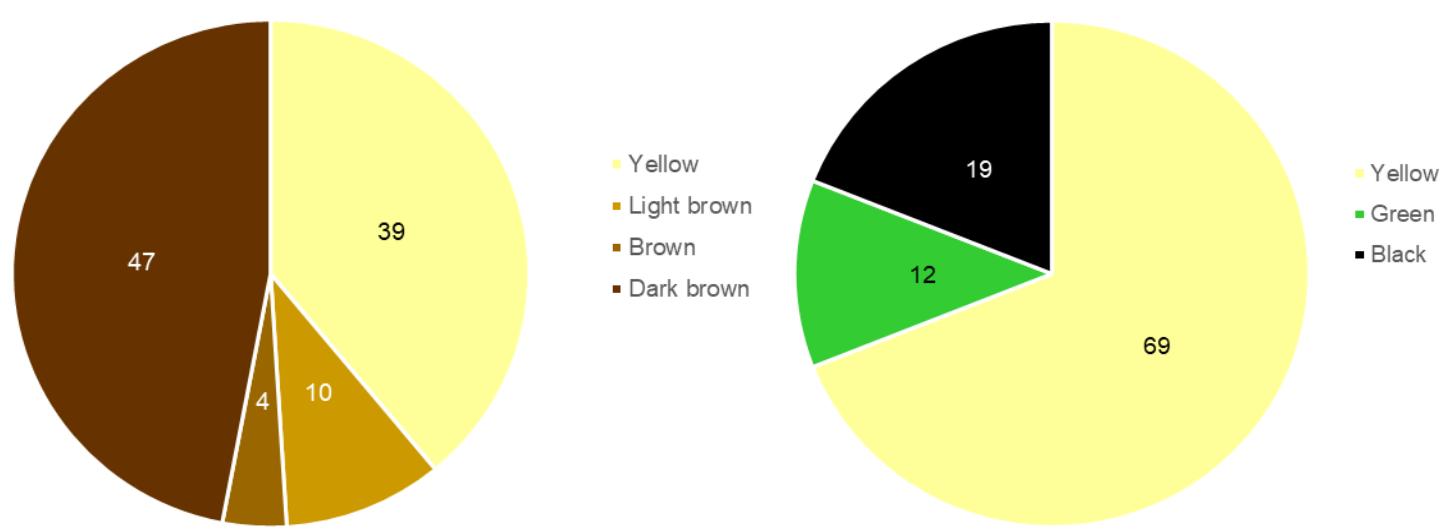

Figure 3. Variability of the pod (left) and seed (right) colors of 100 soybean genotypes 

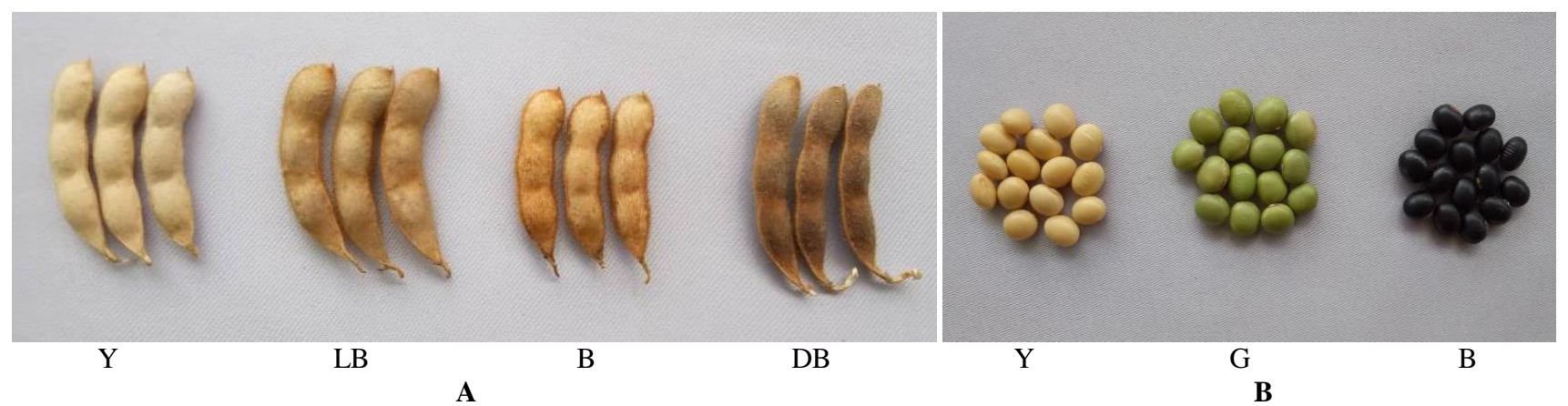

Figure 4. A. Pod color variation (Y: yellow, LB: light brown, B: brown, DB: dark brown), B. Seed color variation (Y: yellow, G: green, B: black)

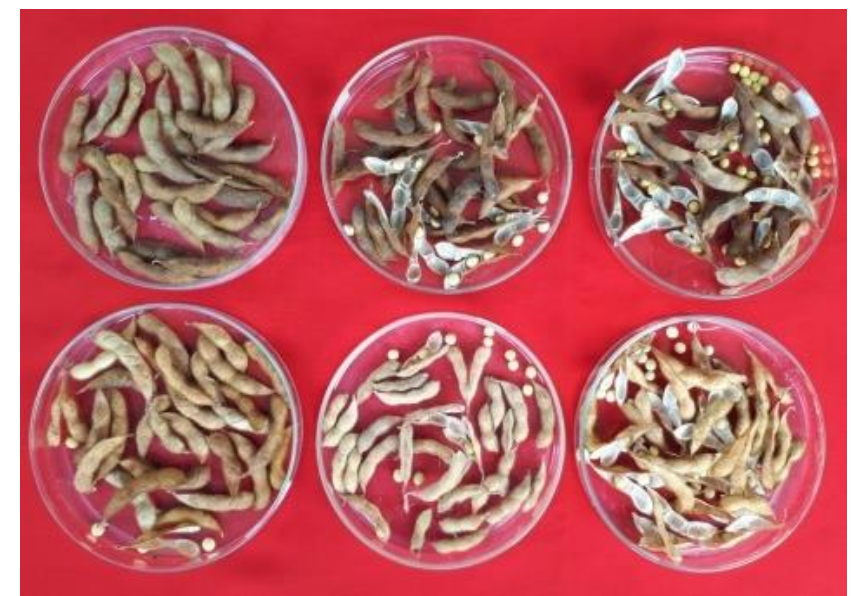

Figure 5. Example of variation in the pod shattering on the different seed and pod colors

Based on the classification of resistance, it was obtained 20 very resistant genotypes, 17 genotypes were classified as resistant, 15 genotypes were moderate, nine genotypes were susceptible, and 36 genotypes were classified as very susceptible. The shattering resistance of check cultivar Dega 1 was very susceptible, whereas the other checks (Derap 1 and Detap 1) were very resistant to pod shattering. A previous study by Krisnawati and Adie (2017) obtained 13 resistant genotypes of 30 tested genotypes derived from crossing with Anjasmoro variety as one of the parentals. In India, an evaluation for pod shattering resistance of 69 soybean genotypes showed the range of shattering from $0.67-67.05 \%$ and it has obtained three resistant genotypes (Bara et al. 2013). Another study has successfully obtained nine resistant and 41 intermediate genotypes to pod shattering (Barate et al. 2018). In Nigeria, Umar et al. (2017) reported that soybean genotypes TGX1955-10E, NG/AD/11/08/023, and NG/SA/07/100 were found to be good general combiners for resistance to pod shattering. The very resistant and resistant genotypes obtained from this study would provide the chance for saving the yield losses due to pod shattering.

\section{Characteristics of very resistant genotypes}

In this study, twenty soybean genotypes with very resistant levels showed variability in the pod and seed color
(Figure 6). The pod color variation consists of seven genotypes with a yellow pod, three genotypes with a light brown pod, a genotype with a brown pod, and nine genotypes with a dark brown pod. Meanwhile, the seed color varies, i.e. 14 genotypes with yellow pod and three genotypes with green and black color, respectively.

The study to find out the effect of the pod and seed color traits in the pod shattering in soybean has never been performed. So far, the identification for the determinant for pod shattering resistance have been conducted from the aspects of morphology (Bara et al. 2013), anatomy (Tiwari and Bhatia, 1995; Zhang et al. 2018), and biochemical factors (Agrawal et al. 2002; Romkaew et al. 2008; Gaikwad and Bharud 2018). Several studies on the pod and seed characteristics related to pod shattering have been conducted.

Table 3. Pod shattering resistance of 14 pedigree (97 genotypes) and three check cultivars

\begin{tabular}{lcccccc}
\hline \multirow{2}{*}{ Pedigree } & $\begin{array}{c}\text { The resistance } \\
\text { Number of } \\
\text { genotypes }\end{array}$ & $\begin{array}{c}\text { Tassification and the } \\
\text { number of genotypes }\end{array}$ \\
\cline { 2 - 7 } & & HR & R & M & S & VS \\
\hline Anjasmoro/Dg & 5 & 0 & 1 & 1 & 1 & 2 \\
Dega 1/Dg & 4 & 1 & 0 & 0 & 1 & 2 \\
Dg/Anjasmoro & 4 & 0 & 1 & 0 & 0 & 3 \\
Dg/Grobogan & 2 & 0 & 0 & 0 & 0 & 2 \\
Dg/IAC 100 & 1 & 0 & 0 & 0 & 0 & 1 \\
Dg/Mahameru & 1 & 1 & 0 & 0 & 0 & 0 \\
G2/PR15 & 1 & 0 & 0 & 1 & 0 & 0 \\
Grobogan/Dg & 20 & 5 & 4 & 1 & 0 & 10 \\
Grobogan/G100H & 7 & 1 & 1 & 0 & 0 & 5 \\
IAC 100/Anjasmoro & 6 & 1 & 2 & 1 & 0 & 2 \\
JP15/Anjasmoro & 39 & 9 & 7 & 10 & 7 & 6 \\
Kh1/Anjasmoro & 3 & 1 & 1 & 1 & 0 & 0 \\
Mahameru/Dg & 3 & 0 & 0 & 0 & 0 & 3 \\
Mahameru/IAC 100 & 1 & 1 & 0 & 0 & 0 & 0 \\
Check varieties: & & & & & & \\
Dega 1 & 1 & 0 & 0 & 0 & 0 & 1 \\
Derap 1 & 1 & 1 & 0 & 0 & 0 & 0 \\
Detap 1 & 1 & 1 & 0 & 0 & 0 & 0 \\
Total & 100 & 22 & 17 & 15 & 9 & 37 \\
\hline
\end{tabular}

Note: VR: very resistant (0\%), R: resistant (1-10\%), M: moderate $(11-25 \%)$, S: susceptible (26-50\%), VS: very susceptible $(>50 \%)$ 

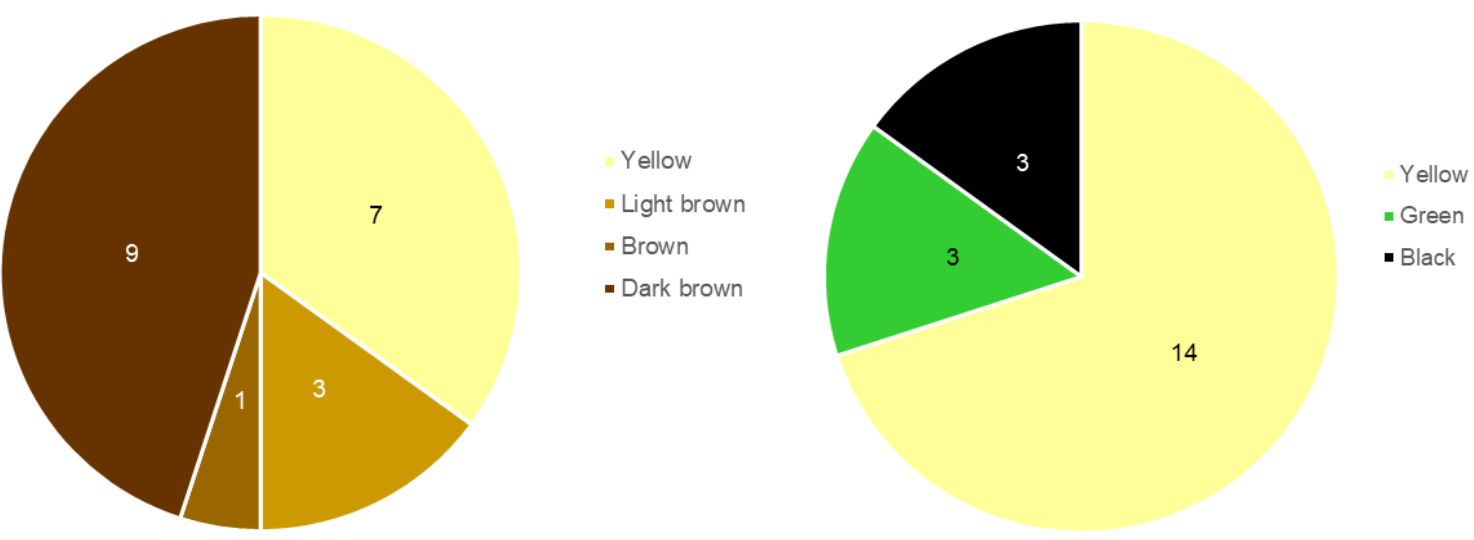

Figure 6. Variability of pod (left) and seed (right) colors of 20 very resistant genotypes to pod shattering

Thompson and Hughes (1986) reported that podshattering was affected by pod attributes such as pod angles, length, and width. Furthermore, Bara et al. (2013) found a higher shattering resistance of a genotype with a small pod, less width, and low volume/weight of seed. Girase et al. (2018) revealed that a lower pod setting height, a smaller number of seeds in a pod, and a thicker pod were less shattered. In a recent study, Krisnawati et al. (2020) revealed that the length of the dorsal and ventral side of the pod, a higher total pod weight, and a larger seed size would increase the degree of the pod shattering susceptibility.

In this study, the effect of the pod and seed color traits in the pod shattering was investigated by identifying the difference in the pod shattering percentage among various seed and pod colors based on Welch's t-test. Based on Table 4, the pod shattering among pod colors was not significantly different. There was no tendency that certain pod colors determine the resistance. A study in common bean also found a non-significant correlation between podshattering with pod color (Murgia et al. 2017). The identification in the difference of pod shattering percentage among various seed color showed that pod-shattering with different seed coat, i.e., between a light color (green or yellow) and dark color (black) was not significantly different (Table 5). However, the pod shattering between green and yellow seed color was significantly different. The yellow seeds tended to have a high shattering percentage than the green seeds. A study by Wang et al. (2007) also found the difference in shattering resistance between different seed colors in Brassica species, but further research showed that the shatter resistance was independent of seed color genes. Thus, it was suggested that the resistance to pod shattering appears to be attributed to their breeding background and selections (Wang et al. 2007), and seed morphological traits, such as seed size (Bara et al. 2013; Krisnawati and Adie 2017; Krisnawati et al. 2020).

\section{Simultaneous selection}

Based on the previous screening for shattering resistance (Table 3), twenty very resistant genotypes were obtained. The seed yield of those selected genotypes ranged from 0.52-3.09 t/ha with an average of $1.92 \mathrm{t} / \mathrm{ha}$ (Figure 7). The seed yield of shatter-resistant check cultivar of Derap 1 and Detap 1 was 2.53 t/ha and 1.39 t/ha, respectively.

Table 4. The Welch's t-test based on the pod color in the pod shattering

\begin{tabular}{lcccll}
\hline \multicolumn{1}{c}{ Pod color } & N & Mean & STD & $\begin{array}{c}\text { SE } \\
\text { Mean }\end{array}$ & t value \\
\hline Yellow & 39 & 40.02 & 3.81 & 0.61 & $1.10^{\text {ns }}$ \\
Light brown & 10 & 61.10 & 4.22 & 1.3 & \\
Yellow & 39 & 40.02 & 3.81 & 0.61 & $0.91^{\text {ns }}$ \\
Brown & 4 & 66.75 & 4.44 & 2.2 & \\
Yellow & 39 & 40.02 & 3.81 & 0.61 & $-0.41^{\text {ns }}$ \\
Dark brown & 47 & 33.36 & 3.30 & 0.48 & \\
Light brown & 10 & 61.10 & 4.22 & 1.3 & $0.19^{\text {ns }}$ \\
Brown & 4 & 66.75 & 4.44 & 2.2 & \\
Light brown & 10 & 61.10 & 4.22 & 1.3 & $1.36^{\mathrm{ns}}$ \\
Dark brown & 47 & 33.36 & 3.30 & 0.48 & \\
Brown & 4 & 66.75 & 4.44 & 2.2 & $1.07^{\mathrm{ns}}$ \\
Dark brown & 47 & 33.36 & 3.30 & 0.48 & \\
\hline Not N: now & & &
\end{tabular}

Note: N: number of genotypes, STD: standard deviation, SE: standard error, ns: not significant $(p>0.05)$

Table 5. The Welch's t-test based on the seed color in the pod shattering

\begin{tabular}{lccccc}
\hline \multicolumn{1}{c}{ Seed color } & N & Mean & STD & $\begin{array}{c}\text { SE } \\
\text { Mean }\end{array}$ & t value \\
\hline Green & 12 & 13.50 & 2.02 & 0.58 & $-3.53^{* *}$ \\
Yellow & 69 & 48.62 & 3.90 & 0.47 & \\
Green & 12 & 13.50 & 2.02 & 0.58 & $-1.24^{\text {ns }}$ \\
Black & 19 & 25.78 & 2.88 & 0.66 & \\
Yellow & 69 & 48.62 & 3.90 & 0.47 & $-1.92^{\text {ns }}$ \\
Black & 19 & 25.78 & 2.88 & 0.66 & \\
\hline
\end{tabular}

Note: N: number of genotypes, STD: standard deviation, SE: standard error, ${ }^{* *}$ : significant $(\mathrm{p}<0.01)$, ns: not significant $(\mathrm{p}>0.05)$ 


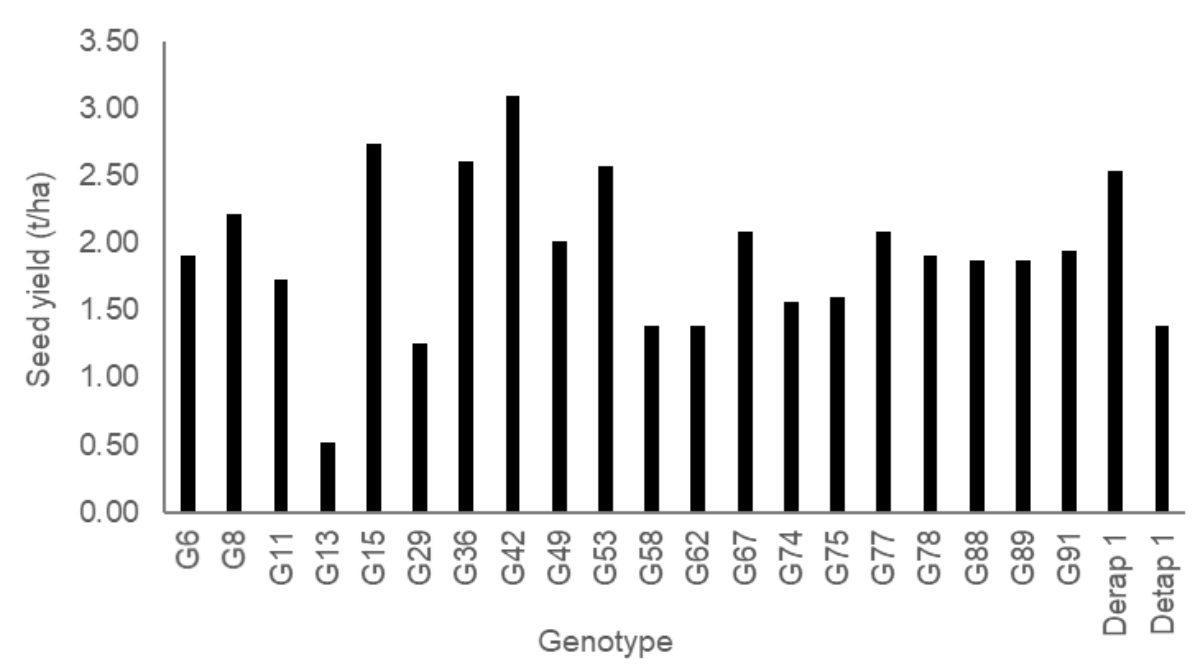

Figure 7. Seed yield of 20 very resistant genotype

If the simultaneous selection was performed based on the seed yield (of the highest yield of check cultivar, Derap 1) and the shattering resistance, then two genotypes were selected with a higher yield than Derap 1, but with similar shattering resistance, namely G42 (3.09 t/ha) and G15 (2.74 t/ha). Those genotypes have medium maturity (80 and 81 days, respectively). The days to maturity could be one of the important factors related to pod shattering. Fatima et al. (2020) found a positive correlation ( $\mathrm{r}=$ $0.346^{*}$ ) between pod shattering and days to maturity. It means that shattering may occur in late-maturing genotypes than in early maturing genotypes. Similarly, Bara et al. (2013) found that the plant age could aggravate the pod shattering. On the contrary, Kataliko et al. (2019) did not found a significant correlation between pod-shattering with days to maturity.

The present finding of this study, i.e., the very resistant genotypes with high yield, could be recommended to be developed as new cultivars; meanwhile, the other very resistant genotypes can be effectively used in soybean breeding programs as gene donors to develop shattering resistant genotypes combined with certain desirable traits. From the research that has been done, it can be concluded that the pod color did not affect the pod shattering resistance of soybean genotypes. Among 100 genotypes, twenty genotypes were classified as very resistant to pod shattering. Two very resistant genotypes (G42 and G15) produce high yield and have medium maturity. Those genotypes were suggested to be developed as new improved cultivars. The other very resistant genotypes could be used as gene donors in the breeding program.

\section{ACKNOWLEDGEMENTS}

The authors acknowledge the Indonesian Agency for Agricultural Research and Development (IAARD), Ministry of Agriculture. The authors would also like to sincerely thank Arifin, for his help during the field research.

\section{REFERENCES}

Adeyeye AS, Togun AO, Akanbi WB, Adepoju IO, Ibirinde DO. 2014. Pod shattering of different soybean varieties, Glycine $\max (\mathrm{L})$ Merrill, as affected by some growth and yield parameters. Intl J Agric Res 2 (1): 10-15.

Agrawal AP, Basarkar PW, Salimath PM, Patil SA 2002 Role of cell walldegrading enzymes pod-shattering process of soybean, Glycine max (L) Merrill. Curr Sci 82 (1): 58-61.

Antwi-Boasiako A. 2017. Screening of soybean (Glycine max (L.) Merrill) genotypes for resistance to lodging and pod shattering. Intl J Agron Agric Res 10 (5): 1-8.

AVRDC (Asian Vegetable Research and Development Centre). 1979. Soybean Report, Shanhwa, Taiwan, Republic of China.

Bara N, Khare D, Srivastava AN. 2013. Studies on the factors affecting pod shattering in soybean. Indian J Genet Plant Breed 73 (3): 270277.

Barate PL, Chimote VP, Deshmukh MP, Kulkarni AA. 2018. Screening of different soybean genotypes Glycine $\max$ (L.) Merrill for podshattering trait. J Agric Sci Technol 43 (3): 517-521.

Bhor TJ, Chimote VP, Deshmukh MP. 2014. Inheritance of pod shattering in soybean [Glycine $\max$ (L.) Merrill]. Electron J Plant Breed 5 (4): 671-676.

De Chavez H, Borromeo T, Borines NO, Gentallan R Jr. 2017. Phenotypic diversity of soybean (Glycine max (L.) Merr.) accessions in the Philippines for utilization. Legume Res 40: 9-15.

Fatima UA, Mohammed MS, Oyekunle M, Abdulmalik MM, Usman A. 2020. Screening soybean (Glycine $\max$ (L.) Merrill) genotypes for resistance to pod shattering in Zaria, Nigeria. FUDMA J Sci 4 (1): 727-731.

Gaikwad AP, Bharud RW. 2018. Effect of harvesting stages and biochemical factors on pod shattering in soybean, Glycine max (L.) Merrill. Intl J Curr Microbiol Appl Sci 7 (11): 1015-1026.

Girase VS, Khedkar DJ, Rajmane VB, Deokar SD. 2018. Evaluation of soybean germplasm for shattering resistance. Intl J Chem Stud 6 (4): 2854-2858.

He Q, Yang H, Xiang S, Tian D, Wang W, Zhao T, Gai J. 2015. Fine mapping of the genetic locus L1 conferring black pods using a chromosome segment substitution line population of soybean. Plant Breed 134: 437-445.

Kataliko RK, Kimani PM, Muthomi JW, Wanderi WS, Olubayo FM, Nzuve FM. 2019. Resistance and correlation of pod shattering and selected agronomic traits in soybeans. J Plant Stud 8 (2): 39.

Krisnawati A, Adie MM. 2017. Variability on morphological characters associated with pod shattering resistance in soybean. Biodiversitas 18 (1): 73-77.

Krisnawati A, Adie MM, Soegianto A, Waluyo B, Kuswanto. 2019a. Pod shattering resistance and agronomic traits in F5 segregating populations of soybean. SABRAO J Breed Genet 51 (3): 266-280. 
Krisnawati A, Soegianto A, Waluyo B, Kuswanto. 2019b. Selection of F6 soybean population for pod shattering resistance. Biodiversitas 20 (1) 3340-3346.

Krisnawati A, Soegianto A, Waluyo B, Kuswanto. 2020. The pod shattering resistance of soybean lines based on the shattering incidence and severity. Czech J Genet Plant Breed 56 (3): 111-122.

Liu W, Qin W, Wu H, Yang C, Deng J, Iqbal N, Liu W, Du J, Shu K, Yang F, Wang X, Yong T, Yang W. 2017. Metabolism variation and better storability of dark-versus light-coloured soybean (Glycine max L. Merr.) seeds. Food Chem 223: 104-113.

Minitab. 2013. Minitab 17. Minitab Inc. USA

Murgia ML, Attene G, Rodriguez M, Bitocchi E, Bellucci E, Fois D, Nanni L, Gioia T, Albani DM, Papa R, Rau D. 2017. A comprehensive phenotypic investigation of the "pod-shattering syndrome" in common bean. Front Plant Sci 8: 251. DOI 10.3389/fpls.2017.00251.

Nevhudzholi KM, Gwata ET, Mchau GRA. 2020. A genetic study of pod shattering resistance in F2 soybean (Glycine max) germplasm. S Afr J Plant Soil 37 (2): 174-176.

Ogutcen E, Pandey A, Khan MK, Marques E, Penmetsa RV, Kahraman A, von Wettberg EJB. 2018. Pod shattering: a homologous series of variation underlying domestication and an avenue for crop improvement. Agronomy 8: 137.

Ramteke R. and Murlidharan, P. 2012. Characterization of soybean (Glycine $\max$ ) varieties as per DUS guidelines. Indian J Agric Sci 82 (7): $572-577$

Romkaew J, Nagaya Y, Goto M, Suzuki K, Umezaki T. 2008. Pod dehiscence in relation to chemical components of pod shell in soybean. Plant Prod Sci 11 (3): 278-282.

Shingare RB, Chimote VP, Deshmukh MP, Bhor TJ, Kale AA. 2020 Verification of soybean seed coat colour specific markers reveals I loci specific markers capable for distinguishing genotypes differing in seed coated colour. Legume Res. DOI: 10.18805/LR-4180.
Tefera H, Kamara AY, Asafo-Adjei B, Dashiell KE. 2009. Improvement in grain and fodder yields of early-maturing promiscuous soybean varieties in the Guinea savanna of Nigeria. Crop Sci 49 (6): 20372042.

Thompson KF, Huges WG. 1986. Breeding varieties. In: Scarisbrick DH, Daniels RW (eds.). Oilseed rape. Collins, London.

Tiwari SP, Bhatia VS. 1995. Characterization of pod anatomy associated with resistance to pod-shattering in soybeans. Ann Bot 72: 483-85.

Tiwari S, Bhatnagar P. 1991. Pod shattering as related to other agronomic attributes in soybean. Trop Agric (Trinidad) 68: 102-103.

Tukamuhabwa P, Dashiell KE, Rubaihayo P, Nabasirye M. 2002. Determination of field yield loss and effect of environment on pod shattering in soybean. Afr Crop Sci J 10 (3): 203-209.

Umar FA, Mohammed MS, Oyekunle M, Usman IS, Ishaq MN, Dachi SN. 2017. Estimates of combining ability for resistance to pod shattering in soybean (Glycine $\max (\mathrm{L}$.) Merrill) genotypes. J Plant Breed Crop Sci 9 (12): 217-223.

Wang R, Ripley VL, Rakow G. 2007. Pod shatter resistance evaluation in cultivars and breeding lines of Brassica napus, B. juncea and Sinapis alba. Plant Breed 126: 588-595.

Yang K, Jeong N, Moon J, Lee Y, Lee S, Kim HM, Hwang CH, Back K, Palmer RG, Jeong S. 2010. Genetic analysis of genes controlling natural variation of seed coat and flower colors in soybean. J Hered 101 (6): 757-768.

Zhang L, Boahen S. 2010. Evaluation of critical shattering time of earlymaturity soybeans under early soybean production system. ABJNA 1 (4): 440-447.

Zhang Q, Tu B, Liu C, Liu X. 2018. Pod anatomy, morphology and dehiscing forces in pod dehiscence of soybean (Glycine max (L.) Merrill). Flora 248: 48-53.

Zhao, G, Wang J, Han Y, Teng W, Sun G, Li W. 2008. Identification of QTL underlying the resistance of soybean to pod borer, Leguminivora glycinivorella (Mats.) Obraztsova, and correlations with plant, pod and seed traits. Euphytica 164 (1): 275-282. 